\title{
¿ERA JUSTIFICADA LA GUERRA CONTRA LOS CHICHIMECAS?
}

MARIANA TERĀN

Universidad de Zacatecas

Alberto Carrillo Cázares, El debate sobre la guerra chichimeca:1531-1585, Zamora, El Colegio de Michoacán-El Colegio de San Luis Potosí, 2000, 761 p. trabajada por Powell, Kieran, Francisco Morales, José Francisco Román, se unen en estos dos volúmenes para tratar la justedad: las causas justas, las rectas intenciones de la corona, el problema de la otredad, la entrada de la evangelización en tierra de guerra, la visión que los europeos tenían sobre los nativos a través de lo que llamamos discurso a debate: "El aspecto político y militar de la guerra chichimeca ha recibido notable atención de historiadores como Phillip W. Powell; sin embargo, el aspecto teológico-jurídi$\mathrm{co}$, que los mismos estudiosos de la historia militar no alcanzan a tratar adecuadamente, está reclamando una particular investigación". (p. 32)

La investigación comienza en 1531 con la conquista de la Nueva Galicia por Nuño de Guzmán, atraviesa la etapa de la guerra del Miztón para poner 
de manifiesto el tipo de discusiones políticas, jurídicas, teológicas y éticas sobre la justedad de la guerra, para terminar con el estado de la cuestión sobre la guerra propuesto en el Concilio Tercero Provincial Mexicano en 1585.

Alberto Carrillo divide su exposición en tres momentos: el primero es la celebración de juntas de teólogos convocadas por el virrey Martín Enríquez de Almanza; el segundo es la reflexión sobre uno de los materiales más ricos y sugestivos que nos hablan de la región, que es el Tratado de la guerra de los Chichimecas, escrito por fray Guillermo de Santa María, y el tercero la consulta realizada a petición de la Real Audiencia en el pleno del Concilio Tercero Provincial Mexicano.

Desde estas tres dimensiones, el autor muestra el tipo de razonamientos y argumentos encontrados, opuestos $y / o$ continuados por los hombres de la iglesia en España y Nueva España.

El problema político de la guerra no deja de ser un problema ético. Lo presupone. La entrada de los misioneros a la región septentrional implicó una relación casi siempre contradictoria entre la conversión pacífica de los naturales a la fe, a través del ejercicio continuo de la predicación y la violencia efectiva de los codiciosos españoles encomenderos. El imperio se extendía en el norte a través de la palabra y de la guerra. Carrillo Cázares se pregunta por el problema de la ética de la guerra, mientras nosotros nos preguntamos por la eficacia, el deleite y la violencia de la palabra.

¿Qué significó para la corona, para la iglesia indiana, y para la administración novohispana la región indómita, hostil, desconocida, y bárbara de la gran chichimeca? ¿QQué significó esta región a primeras luces uniforme y homogénea desde los ojos civilizados de occidente, desde los estudiosos en las bibliotecas salmantinas, desde las tierras conquistadas de Mesoamérica? ¿Cómo dimensionaron y juzgaron a la región norteña los que llegaron y se asentaron en el centrosur de Nueva España?

Es impresionante la presencia de un discurso múltiple y heterogéneo para tratar el problema ético de la guerra y el problema político de la paz. Así en la paz como en la guerra, los teólogos buscaron justificarla o denunciarla. Cómo no hacer guerra y enfrentar militarmente a los indios rebeldes si éstos contaminaban a los ya convertidos, si se infiltraban en los caminos para robar y matar, si estaban acechando amenazantes en una zona tan es- 
tratégica por su potencia económica como lo eran los caminos que unían a los centros mineros con las ciudades de Zacatecas, México, y Guadalajara (p. 43). La percepción de la frontera se amplió porque se reconoció un territorio extraordinario para su explotación. Cómo no hacer la guerra y matar a los que rechazaban la buena palabra, representando un significativo obstáculo para el avance y extensión del imperio. Frente a la duda indiana, se fue dimensionando la duda sobre la guerra chichimeca. No eran lo mismo los dóciles indios sedentarios, que los guerreros nómadas del norte. Cómo controlar y hacer extensivo un poder cuando los otros andan salteando por los caminos, moviéndose de una región a otra, atacando a los diferentes. Cómo establecer misiones y predicar la palabra cuando el otro se oculta y termina por irse; cuando el otro practica la idolatría, los sacrificios humanos, los vicios contra natura y el comer carne humana (p. 86).

No es ajena a esta situación la problemática que vivieron los franciscanos y jesuitas para asentarse en la Pimería Alta llevados por el mito de una tierra llamada Cíbola, donde encontrarían oro y riquezas. Por el contrario, con lo que se toparon fue con un grupo de indios nómadas y su pro- blema se tradujo en cómo convertirlos cuando estaban aquí y al mismo tiempo estaban allá. El fin justifica los medios: salvar las almas perdidas y dilatar el señorío hispano justifica el acto de matar y esclavizar cuando se oponen a este fin.

Pero, en contrapartida, ¿dónde está la justicia cuando se hace la guerra? ¿Cuáles son las llamadas causas justas? ¿Qué justifica enfrentar y matar? Los defensores de los medios pacíficos, como Bartolomé de las Casas y Vasco de Quiroga, no dejaron de argumentar que esos otros, aunque feroces, eran hombres racionales. Los infieles, aunque infieles, tenían derecho a sus propiedades, la guerra era injusta; en este sentido, convertir a los indios no debía llevar a privarlos de sus títulos legítimos. Frente a la alternativa de que los maten infieles, mejor que los hagan cautivos y bauticen (p. 128).

El debate, que representara una discusión en el terreno teórico, encontró eco en la dimensión de la experiencia vivida por los que compartieran su vida con los naturales; el debate dejó de ser una discusión entre teólogos y juristas españoles para continuarse por los novohispanos que vivieran el otro territorio: "[...] a partir de la duda sobre la justicia de la guerra que se hace a los indios de Ja- 
lisco, los planteamientos que se hagan sobre la ética de la guerra dejarán de ser teóricos y comenzarán a aplicarse a hechos concretos y comprobables" (p. 93). El autor expone, a través de la pluma de Fray Guillermo de Santa María, en el Tratado sobre la guerra de los chichimecas, el valioso discurso de carácter etnográfico que se encuentra en este material. Para juzgar al otro, primero conocerlo. Entre sus pareceres, el misionero agustino relata el tipo de vida de los chichimecas: bailes, fiestas, armas, modos de pelear, matrimonios, sustento, vestido, vivienda. Carrillo Cázares refiere la importancia de este tipo de textos por su rico material etnográfico; sin embargo, en su tratamiento crítico de las fuentes, corrige la opinión tan extendida entre etnólogos e historiadores en el sentido de que el autor del Tratado era Gonzalo de las Casas. No, el verdadero autor es fray Guillermo de Santa María. "Ninguno fue tan explícito y firme como Fray Guillermo en denunciar el cargo de conciencia grave de quienes perseguían, cautivaban y vendían chichimecas inocentes, como autores directos e indirectos de grave daño y escándalo" (p. 283).

Frente a la situación que prevé el fraile sobre el despoblamiento provo- cado por la guerra, advierte sobre los medios pacíficos para incursionar en tierra adentro. Poblar la zona, adoctrinar a los indios, darles los medios para que vivan en paz, eliminando la imagen que se tiene del español codicioso que sólo busca la riqueza y la esclavitud.

La obra de Alberto Carrillo merece una atenta lectura por parte de historiadores y etnólogos por varias razones: 1. Trata un problema que se había quedado al margen: el problema ético de la guerra; 2 . Hace un excelente balance sobre los múltiples discursos acerca de la guerra traídos desde España, discutidos y vividos en Nueva España; 3. Redimensiona un acontecimientd como la guerra del Miztón desde las largas tradiciones jurídicas y teológicas que le otorgan sentidos potenciales; 4 . El segundo volumen es una rica documentalia que orienta a los nuevos estudiosos sobre el tema, el territorio y la sociedad.

Finalmente, esta obra merece leerse por su actualidad, es decir, su aparición en un momento en que nos preguntamos nuevamente por la guerra, por su sentido, por sus desconocidas causas en su nueva edición globalizadora. 